\title{
Comparing the Protests of Undocumented Migrants Beyond Contexts: Collective Actions as Acts of Emancipation
}

\begin{abstract}
In this article, we demonstrate that the collective actions of undocumented migrants possess similar symbolic dimensions, even if their contexts differ. We explain this argument by focusing on the power relations that undocumented migrants face. Given that they occupy a very specific position in society (i.e., they are neither included in nor completely excluded from citizenship), they experience similar forms of power relations vis-à-vis public authorities in different countries. We argue that this leads them to participate in collective actions as acts of emancipation. Our analysis illustrates this argument by comparing marches of undocumented migrants in three countries: France, Germany and Canada-Quebec. Through an in-depth analysis, we demonstrate that these marches redefine the legal order and politicize the presence of undocumented migrants in the public sphere. By highlighting the cognitive, emotional and relational dimensions of collective actions, we show that the symbolic dimension of these three marches relates to the empowerment, pride and solidarity of undocumented migrants.
\end{abstract}




\section{Introduction}

Undocumented migrants usually mobilize to demand that governments end deportation and detention policies and initiate a regularization of their status as residents. Beyond these claims, however, their protests also possess a symbolic dimension, in the sense that their mobilizations are based on behaviours, objects, images, texts or speech acts that evoke, by reference or by association, more general political dimensions (Swidler, 1986; Williams, 2004). ${ }^{1}$ In this paper, we show that the symbolic dimension of the collective actions of undocumented migrants is similar in different contexts and expresses the same meaning: the redefinition of the limits of the legal order within a territory. Our demonstration is based on a comparison of the collective actions launched by the most significant networks of undocumented migrants in France, Germany and Canada-Quebec over the last decade. We develop our analysis by focusing on three protest events (three long-term marches) that played a central role in this period.

Our argument is counter-intuitive: scholars exploring the cultural and symbolic dimensions of social movements in a comparative perspective demonstrate that they are shaped by their national contexts. In particular, laws, public policy-making, as well as institutional discourses and practices, are crucial elements: they constrain and channel the cultural production of social movements because they set the terms of the debate. By defining 'familiar ways of doing things and seeing things' (Polletta, 2008: 86), they determine to a large extent what is meaningful in the

\footnotetext{
${ }^{1}$ Our analysis of the symbolic dimension of collective actions is related to the broader literature on culture in social movements (Goodwin, Jasper and Polletta, 2001; Johnston and Klandermans, 1995; Polletta, 2002, 2004; Williams, 2004).
} 
public sphere and, as such, what movements are able to express and achieve (Marx Ferree et al., 2002; Evans, 1997; Polletta, 2000, 2004). For example, the way institutions 'construct the relation between immigrants and the receiving nation-state' (Koopmans and al., 2005: 18-19) is crucial with regard to the cultural dimension of migrants' mobilizations. Different ways of building this relationship will create different 'discursive opportunity structures', and movements will base their mobilizations on different cultural features in order to adapt to them (Koopmans et al., 2005). By extension, we might expect that the manner in which institutions construct the relationship between immigrants and the state also has an influence on the symbolic dimension of the collective actions of undocumented migrants. In particular, because they reveal the presence of undocumented migrants in the public space, marches should be particularly sensitive to the features of the national contexts, and as a result, their meanings might be expected to differ in different settings.

We know that France, Germany and Canada are characterized by three different 'philosophies of integration' (Favell, 1998). In Canada, the federal government's multicultural paradigm dominates the way immigrants and the state interact: the state assigns identities to immigrant groups and selects immigrants on the basis of cultural or ethnic criteria (Kymlicka, 1995; Labelle, Rocher and Antonius, 2009). In Quebec, more specifically, immigration policies are defined through an 'intercultural' framework, which differs slightly from the federal multicultural approach where immigrants are invited to embrace the dominant French culture and, at the same time, are invited to preserve their own cultural differences (Bouchard and Taylor, 2008). French integration policies are, for their part, defined by a universalist republican paradigm (Schnapper, 2004; Koopmans et al., 2005). Despite changes in recent times, immigration policies remain 
unitary and traditionally unfavourable to pluralism. The German case represents an 'exclusive' type of regime. Until the end of the 1990s, immigrants were considered to be 'guest-workers' (Herbert, 2001), and the jus-sangui law impeded their political inclusion (Brubaker, 1992). This has led to an 'institutionalized separateness' (Brubaker, 2001), which persists despite recent changes to public policy (Borkert and Bosswick, 2007: Koopmans et al., 2005; Heckmann, 2003)..$^{2}$

Considering these highly contrasting contexts, we might expect the marches of undocumented migrants to express different meanings in France, Germany and Quebec. Furthermore, we might expect these marches to symbolically define their presence in the public space through references to the republican state in France, to the state of origin in Germany and to the diaspora of minority groups in Quebec. Our research shows, however, that this is not the case.

Contextual differences may explain variations in some aspects of the collective actions of undocumented migrants, as is the case for the mobilizations of 'regular' immigrants or ethnic

${ }^{2}$ These three cases differ in terms of their institutional settings, but they are comparable with respect to the populations of undocumented migrants living in their respective territories. Although it is impossible to calculate the exact number of undocumented migrants living in a territory, several estimates provide a good idea of the figure: between 50,000 and 100,000 undocumented migrants live in Canada (Khandor et al., 2004); between 200,000 and 400,000 live in France (Courau, 2008); and between 100,000 and 1,000,000 million live in Germany (Cyrus, 2008). 
minorities. ${ }^{3}$ We argue, however, that the symbolic dimension of their collective actions is shaped first and foremost by their specific and unique position in the territory. Undocumented migrants are not recognized by the state as legal actors, but they are included in the public space on a dayto-day basis (i.e., they work, go to school and even pay taxes). This position (i.e., not included nor totally excluded) means that they are subject to governmental practices that fall outside of the public authorities' normal legal order (Bigo, 2007; Fassin, Morice and Quiminal, 1997). In the following pages, we show that the symbolic dimension of the mobilizations of undocumented migrants is shaped by this particular situation: whatever the specifics of the national context in which they mobilize, the meaning of their actions is connected to the triggering of a process of emancipation of protestors from state power. This does not mean that the context has no effect on the building of claims and the meaning of struggles, and we will see in the last section of the paper that it does play a role to a certain extent. Nevertheless, at a general level, the symbolic dimension of collective actions is similar in these three cases.

We illustrate this notion by focusing on one particular form of collective action: long-term marches. As shown in the literature, networks of undocumented migrants use radical forms of actions in which they subject themselves to physical suffering, such as hunger strikes (Siméant, 1998) or lip-sewing (Edkins and Pin-Fat, 2005). These actions symbolically emphasize the consequences of their condition of exclusion from citizenship. However, they also use less extreme and more traditional forms of collective actions such as long-term marches (Lomnitz, 2007). Marches are one-time events that, for organizational reasons, cannot be carried out on a

\footnotetext{
${ }^{3}$ Koopmans et al. (2005) has shown that the formal and cultural dimensions of the national citizenship regimes have an influence on the claims constructed by these movements in Europe.
} 
regular basis. However, they do have a great significance in the repertoire of collective actions of undocumented migrants and of movements of the excluded in general (Chabanet, 2002). In this paper, we focus on this specific form of collective action and demonstrate that, like the more radical forms, marches also have a strong symbolic dimension. More specifically, we show that these marches express a transformation of the presence of undocumented migrants in the territory: in contrast with the institutional definition of their presence as a legal 'anomaly', this form of collective action means a politicization of their presence in the public space.

In the next section, we propose a theoretical framework that establishes a connection between the symbolic dimension of collective actions and an analysis of power relations (Armstrong and Bernstein, 2008). In so doing, we draw on recent theories that focus on the performative dimension of collective actions (Isin and Nielsen, 2008): we consider the mobilizations of undocumented migrants as acts of emancipation. Then, we define in greater detail the types of power relations that undocumented migrants face. In the last section, we present the symbolic dimension of the collective actions of undocumented migrants in France, Germany and Canada (Quebec), ${ }^{4}$ and we illustrate our argument through three long-term marches. First, however, we present in greater detail the methods and sources used for this comparative analysis.

\section{Methods and sources}

\footnotetext{
${ }^{4}$ With regard to the Canadian case, we believe it is important to take into account the specific policies adopted by the provincial government in Quebec regarding immigration issues, given that the federal and provincial governments share responsibility for it.
} 
Our research is based on a comparison of movements of undocumented migrants that are active in three major cities: Paris, Berlin and Montreal. ${ }^{5}$ As shown in appendix 1, we have selected 16 groups and networks (7 in Paris, 4 in Montreal and 5 in Berlin) that have been active in mobilizing in favour of the inclusion of undocumented migrants in recent years; they have been responsible for some of the most significant mobilizations for the rights of undocumented migrants in these three cities over the last decade. We focus on two types of collective actors: groups or networks composed exclusively of undocumented migrants (e.g., the $9 e$ Collectif des Sans-Papiers (9th Collective of Undocumented Persons) in Paris, the Coalition Against the Deportation of Palestinian Refugees in Montreal and the Voice Refugee Forum in Berlin) and networks composed of undocumented migrants and other individual or collective actors, such as trade unions (e.g., Réseau Education Sans Frontières (Education Without Borders Network) in Paris, Solidarity Across Borders in Montreal or No Lager in Berlin). These groups and networks vary in terms of their organization, history and scope of mobilization.

To compare their mobilizations systematically, we collected approximately 250 public documents published by these groups and networks from 2000 to 2009. These documents (e.g., communiqués, calls for demonstrations, petitions) were produced in the course of and for the purposes of their mobilizations. The groups and networks organize and publicly justify collective actions, such as demonstrations, marches, public meetings, lobbying campaigns, occupations and hunger strikes. They also present 'softer' forms of mobilizations, given that they include all

\footnotetext{
${ }^{5}$ We chose the city as a unit of analysis because undocumented migrants organize their mobilizations primarily at the local level (Siméant, 1998) and because it allows us to build a comprehensive sample in a limited territory.
} 
public discursive actions that aim to present a situation as problematic, to criticize, to blame, to explain, etc. For instance, they present a general reflection of undocumented migrants' living conditions or of racism in society.

Our analysis consisted of a two-step approach. First, we performed a comparative analysis of the documents by focusing on claims: we systematically coded claims-making events and their discursive dimensions. This method was inspired by Koopmans and Statham (1999). However, our use of it differs somewhat, given that we focused exclusively on the claims formulated by movements and did not rely on newspapers as a source of evidence for these acts of claimsmaking. We consulted the groups' archives (most of them were available on their websites or on distribution lists). This first step provided us with a comprehensive view of undocumented migrants' protests in our three cases. In the second step of our analysis, we focused on a smaller number of events (35) that were the most relevant in terms of their symbolic dimension, and we performed an in-depth contextualized analysis of their content, focusing on their meaning. We analyzed the symbolic textual references, behaviours and images that were put forward in the course of these actions and that provided them with a meaning extending beyond the scope of the claims formulated.

Among these actions, marches appeared particularly meaningful because they set the stage for the presence of undocumented migrants in the public space. In this paper, we present an in-depth analysis of three marches selected based on their comprehensiveness and exemplarity. Although these three collective actions belong to the same repertoire, their symbolic dimension is illustrative of other forms of actions carried out by undocumented migrants. As we will discuss 
in the last section of our article, the focus on these three specific actions is meant to illustrate a broader argument concerning the meaning of the collective actions of undocumented migrants.

\section{The acts of emancipation of undocumented migrants}

Armstrong and Bernstein (2008) have recently emphasized the link between the cultural (or symbolic) dimension of collective actions and the power relations experienced by activists. Culture is connected to the 'nature, logic, and organization of power' (Armstrong and Bernstein, 2008: 93). In their 'multi-institutional politics approach', they link 'forms of domination and forms of movement' (Armstrong and Bernstein, 2008: 81), and they seek to place culture at the core of these forms of domination as well as at the core of social movements' goals and strategies. As a result, they propose 'a research agenda that focuses on how power works across a variety of institutions; how activists interpret, negotiate, and understand power; and how and why activists choose strategies and goals' (Armstrong and Bernstein, 2008: 93). They explain that institutions are extremely powerful given that they 'have both material and social power' (Armstrong and Bernstein, 2008: 81): they create categories (or 'meaning systems') that come to be accepted and are reproduced through social practices. ${ }^{6}$ As such, culture is both a goal and a constraint for social movements. Activists seek cultural changes because they want to challenge the meaning systems defined by institutions. However, they are also constrained by these meaning systems throughout the construction of their collective actions. For example, in her analysis of the gay and lesbian movement in San Francisco, Bernstein (1997) underlines that its mobilization strategies were adopted in order to achieve legal changes (e.g., the repeal of the

\footnotetext{
${ }^{6}$ See also Polletta $(2002,2004)$, Swidler (2001) and Williams (2004).
} 
laws criminalizing homosexuality), as well as to challenge a more general system of meaning that denigrates homosexuality. These strategies explain why the gay movement defines its cause through a strong public dimension (i.e., leading to the construction of a gay identity in the public sphere) and not solely by defending a 'private' sexual life (i.e., as the sole purpose of legal change would imply). Bernstein therefore explains why 'coming out' behaviours in public spaces, such as holding hands, were considered to be acts of political protest.

We propose to build on Bernstein and Armstrong's approach by regarding collective actions as concrete practices that allow activists to renew and transform the power structure in which they are embedded. The symbolic dimension of collective actions refers to the set of strategies that aim to challenge this power structure through cultural changes, such as changes in the understanding of problems, changes in nomenclature, changes in beliefs and values, etc. These strategies are put into practice through highly diversified actions: the formulation of alternative discourses and collective identities, the choice of a specific organizational structure, the choice of a specific place or repertoire of collective actions and the use of specific behaviours (Jasper, 1997; Polletta, 2008). They are designed to challenge the 'meaning systems' on which the power structure is based.

In this perspective, and following Isin and Nielsen (2008), we focus on the 'performative' character of collective actions. On their own, collective actions are moments of rupture that produce new power relations (Isin and Nielsen, 2008; Nyers, 2008; see also della Porta, 2008; Hamel, 1995; Benford and Hunt, 1992; Williams, 2004). Collective actions open up new political possibilities. They are "collective or individual deeds that rupture socio-historical 
patterns' (Isin and Nielsen, 2008: 2). When they act collectively, people do not repeat 'institutionally accumulated processes' (Isin and Nielsen, 2008: 10); rather, they participate in new processes. In other words, a collective action is not only a protest against a specific power relation; it is a moment in which people express a potential to challenge and redefine this power relation. As explained by Isin (2009), the use of the term 'act' allows us to describe this performative dimension and relate it directly to the form of the collective action: 'acts can refer both to deeds as well as performance, to process as well as outcomes, to conduct as well as enactment' (Isin, 2009: 378). Applied to undocumented migrants, ${ }^{7}$ collective actions can be more precisely defined as 'acts of emancipation': they are the actions that trigger emancipatory processes from power relations considered to be unjust. ${ }^{8}$

${ }^{7}$ Isin and Nielsen (2008) refer mainly to citizenship in their analysis: they build on the concept of 'acts of citizenship'. The issue of citizenship is, however, ambiguous in the case of undocumented migrants (Walters, 2008). Since they are excluded from it, they do not necessarily formulate their claim in terms of citizenship (as suggested by slogans such as 'No border'). Citizenship is only mobilized when the access to citizenship is considered beneficial for those who mobilize (Hindess, 2004).

${ }^{8}$ This definition is similar to the definition of 'acts of demonstration' proposed by Walters (2008): they 'occur when an injustice is revealed, a relationship of power is contested, or a particular wrong is protested, but when the identity of the subject at the heart of the protest is left relatively open' (Walters, 2008: 194). However, we use the term 'emancipation' rather than 'demonstration' in order to draw attention to our suggestion that these collective actions are oriented toward challenging specific power relations. 
As della Porta (2008) points out, protests (and collective actions in general) are 'eventful' (Sewell, 1996): they provide a transformative power to protestors and movements alike. More specifically, she distinguishes three effects: cognitive, emotional and relational (della Porta, 2008). Protest can change protestors' views of power relations and produce cognitive processes such as 'cognitive liberation' (McAdam, 1982); episodes of contention can also generate emotions among participants (Goodwin, Jasper and Polletta 2001); and collective actions can produce or reinforce networks and personal connections among participants, deepening and/or extending the scope of solidarities (Dufour, Masson and Caouette, 2010).

Collective actions constructed by undocumented migrants are designed to perform an act of emancipation for the activists involved and for undocumented migrants in general. Highlighting the categories of cognition, emotion and relations described above, we show that in the course of these marches, undocumented migrants produce-or perform-empowerment, pride and solidarities. These performances are highly symbolic because they signify an emancipation from the position they occupy in society; they signify a politicization of their presence in the public space.

In the next section of this paper, we analyze the position that undocumented migrants occupy in society and the types of power relations they face on a daily basis vis-à-vis public authorities.

\section{Undocumented migrants and the state of exception}


By definition, the condition of undocumented migrants regarding citizenship is exceptional: their presence in the territory is not recognized legally by public authorities. However, the absence of legal recognition does not mean that public authorities simply ignore their presence. Certain relationships do exist between the two. The 'state of exception' concept (Agamben, 1998) can be used in order to envisage this very specific power relation (Buckel and Wissel, 2010; Walters, 2008).

In his political theory, Agamben has used the ancient Roman law term homo sacer to describe the condition of those who are 'banned' from citizenship and who consequently live in a space that is neither fully inside nor outside the legal order (best envisaged as a type of 'camp'). In these spaces, the 'normal law' no longer applies: individuals are governed by a 'state of exception'. They are situated in a 'zone of illegalization' and 'at the limits of democracy and law' (Bigo et al. 2008; Buckel and Wissel, 2010). Agamben draws a distinction between two forms of life: the zoë or 'bare life' (simply being alive), and the bios (the social presence in the world). Thus, the homo sacer experience a form of bare life: they are depoliticized; 'deprived from their human rights by lack of citizenship, they can only claim to stay alive' (Fassin, 2005: 367). More specifically, their condition is fully determined by the public authority's disciplinary management and, at the same time, is dependent upon the humanitarian assistance the same authorities offer. ${ }^{9}$ As Agamben argues, groups like refugees and undocumented migrants experience the most extreme forms of bare life (Agamben, 1998: 160). In short, 'the refugee as "homo sacer" describes the condition of exclusion that those exempt from the normal

\footnotetext{
${ }^{9}$ As shown by Fassin (2005), immigration policies are characterized by 'compassion and repression'.
} 
sovereignty are subject to' (Rajaram and Grundy-Warr, 2004: 41). In particular, the paradigm of the 'camp', which is a territorial materialization of the state of exception (Buckel and Wissel, 2010; Fassin, 2005), is particularly relevant to the situation of undocumented migrants and refugees: it is 'the space that opens up when the state of exception starts to become the rule' (Agamben, 2000: 39).

Many recent studies have shown that, over the last few years, the 'camp' has become a rule for the management of migrants by public authorities: those arriving in a territory, facing a deportation measure or in the process of seeking asylum are often confined for indeterminate periods in closed spaces where the 'normal state of law' does not apply (Bigo, 2007; Diken, 2004; Rajaram and Grundy-Warr, 2004; Kobelinsky and Makaremi, 2009; Walters, 2008). By extension, the paradigm of the 'camp' does not only concern those who are confined in these particular spaces: it is always present in the life of undocumented migrants because they are constantly facing the risk of being arrested and detained before being deported (Fassin, 2005).

As we demonstrate in the last part of this paper, the collective actions of undocumented migrants, irrespective of their specific claims, represent a direct challenge to the state of exception in which they live. The in-depth analysis of three marches shows how the symbolic and performative dimensions of their collective actions interrelate. It shows, moreover, that despite some differences, they present strong similarities.

\section{'Why we are marching': three examples of acts of emancipation}


Our in-depth analysis of the collective actions of undocumented migrants in France, Germany and Quebec indicates that as they reveal their presence in the public space, they instil it with specific meaning. For undocumented migrants, the construction of collective actions signifies $a$ politicization of their presence in the public sphere and a way to become emancipated from their condition of bare life. First, in the course of their protest, activists build autonomous spaces of life that allow undocumented migrants to regain power over their own situations. Second, their collective actions define spaces of visibility, which allows for the expression of feelings of pride. Third, the creation of relational ties among activists in the course of their protest allows for solidarity-building. These cognitive, emotional and relational effects share a common element: they push 'the question of the speaking subject front and centre' and 'provoke fundamental questions about politics [and] who can be political' (Nyers, 2003: 1089). These collective actions are acts of emancipation, therefore, because they directly challenge the definition of undocumented migrants' lives as being apolitical in the state of exception. The three examples that serve to illustrate our argument are the long-term marches that took place in Canada, France and Germany in the second half of the 2000s.

Our first example is the 'March to Ottawa', organized in 2005 by Solidarity Across Borders (and by No One Is Illegal) ${ }^{10}$, a network that has been active in Montreal since the mid-2000s. It is composed of migrants without legal status, migrants who do have legal status and Canadian

\footnotetext{
${ }^{10}$ The two groups share most of their activities, and many of their members are active in both groups. For this reason, when we refer to the network Solidarity Across Borders, we imply that No One is Illegal is also involved in the activities analyzed.
} 
citizens with an immigrant background. Its general claims concern 'the struggle for justice and dignity of immigrants and refugees', ${ }^{11}$ and its main demands are 'the regularization of all nonstatus people (Status for All!), an end to deportations and detentions, and the abolition of security certificates". ${ }^{12}$ In Quebec, Solidarity Across Borders is the most active and significant group seeking the legalization of undocumented migrants that comprises member-activists with different legal statuses and from various countries of origin. The majority of the other groups that actively promote this issue in Quebec are composed of immigrants from the same country of origin or of more general human rights associations in which the great majority of the activists do not have an immigrant background. The March to Ottawa was the first significant collective action organized by Solidarity Across Borders. From June 18 to 25, 2005, up to 1000 activists and supporters (i.e., at its high point) marched from Montreal to Ottawa to demand that 'a full regularization program for refugees and non-status people be implemented immediately'. ${ }^{13}$

Our second example is the march from Paris to Nice, which was organized by the Coordination des Sans-Papiers 75 (CSP 75) and activists from their support networks in May 2010. This march was associated with the occupation of a building in Paris. The CSP 75 was created in 2008, when a major strike movement was launched by undocumented migrant workers. It was the most significant network of undocumented migrants involved in this strike. This movement advocated for the regularization of undocumented migrant workers, and it was coordinated, in the beginning, by the trade union CGT (Confédération Générale du Travail (General Labour

\footnotetext{
${ }^{11}$ Solidarity Across Borders, 'About Solidarity Across Borders'.

12 Ibid.

${ }^{13}$ Solidarity Across Borders, 'Why We Are Marching', June 2005.
} 
Confederation)). Some of the undocumented migrants living in Paris soon expressed their dissatisfaction with the CGT and organized the CSP 75. They demanded the regularization of all undocumented migrants and accused the CGT of using them for its own purposes. From May 2008 to June 2009, approximately 500 undocumented migrants from the CSP 75 occupied the Bourse du Travail in Paris, where the CGT's offices were located, in order to put pressure on the trade union. After being evicted in June 2009, the CSP 75 occupied another building north of Paris, where they remained until August 2010. These activists immediately renamed the occupied building the 'Ministry for the Regularization of All Undocumented Migrants'. At the same time, a group of undocumented migrants organized a march from Paris to Nice, where a summit on immigration issues bringing together the French government and the heads of African states took place. This march was organized in order to pressure political decision-makers for the regularization of undocumented migrants.

Our third example is a 'tour' across Germany organized by the Caravan for the Rights of Refugees and Migrants in May and June 2007. The Caravan is a nation-wide network created at the end of the 1990s by groups of asylum-seekers and undocumented migrants protesting against racism, deportations and the 'residence obligation law' (Residenzpflicht) ${ }^{14}$, and for the regularization of all undocumented migrants. It is the most significant network of undocumented migrants that is active in Germany, and it is composed of several groups present in the largest German cities. In Berlin, the network is represented by the group The Voice Refugee Forum. As its name suggests, one of the Caravan's main forms of collective action is the organization of

\footnotetext{
${ }^{14}$ The Residenzpflicht obliges asylum-seekers and refugees with a temporary status to live in reception centres.
} 
regular 'protest tours' across Germany. In fact, the network was officially launched after a sixweek protest tour throughout Germany in the summer of 1998. These tours are a similar form of collective action to marches, although they are organized differently: undocumented migrants travel from one city to another and organize a set of collective actions in every city in which they stop (i.e., they do not march from one city to the other). The tour organized in May and June 2007 was designed to demand of regularization of undocumented migrants, as well as to protest against the G8 Summit, which took place in Heiligendamm, in the north of Germany. Its arrival therefore coincided with the larger counter-Summit organized by the global justice movement (i.e., the first day of protest was dedicated to the struggle against racism and for freedom of movement). ${ }^{15}$

These three cases differ with regards to the networks involved, the contexts of emergence and even the specific claims. However, from the point of view of their symbolic dimension, they are similar in that they redefine the presence of undocumented migrants in the public space through the performance of cognitive, emotional and relational processes.

The cognitive effects of collective actions and the building of an autonomous space of life

First, in all three cases, marches are an opportunity for undocumented migrants to regain power over their own lives. The march aims to produce a cognitive effect on those who participate: it makes them aware of the notion that, despite their situation of legal exclusion, they can

${ }^{15}$ Caravan for the Rights of Refugees and Migrants, 'Solidarity Against Deportation. Call for the CARAVAN tour from May 19 to June 4, 2007’, May 2007. 
formulate claims in the public space like other social groups and can therefore act as citizens who have a legal residence status.

In the march from Montreal to Ottawa, this dimension is apparent in the choice of a symbolic date, which is seen in the historical references in the call launched by Solidarity Across Borders:

We march on the 10th anniversary of the "Bread and Roses" March against poverty, organized by Quebec women, and the 70th anniversary of the On-toOttawa Trek, organized by unemployed workers during the Great Depression; we march in the tradition of those previous efforts for social and economic justice. ${ }^{16}$

The choice of this date is meaningful: by referring to former protest events, the activists aim to associate their mobilization with earlier mobilizations that were considered to have successfully changed power relations. Moreover, the reference to social groups, such as women and unemployed workers, which have exercised their citizenship rights, is a direct challenge to their exclusion from citizenship: protestors are symbolically integrated into a more general struggle for 'social and economic justice', implying that they are exercising their rights as citizens. More generally, this cognitive effect of empowerment aims to transform undocumented migrants from subjects to actors. In the same document, therefore, the march is described as a way to regain power over one's own life. It is defined as the construction of an autonomous space of life:

${ }^{16}$ Solidarity Across Borders, 'Why We Are Marching', June 2005. 
For every arbitrary detention, for every summary deportation, for every minute spent in jail without charge or trial, for every anxious and dehumanizing day spent waiting for status-all the days, months, years that the government has stolen from us-we will take back minute by minute, with every step, on our march from Montreal to Ottawa. Join us and take back stolen time. ${ }^{17}$

In France, the march, which is described as a 'bright event', is seen as the first step in a larger process and is related to former collective actions that have led to the regularization of undocumented migrants:

A seed has been sown and this seed is going to grow. Other more important marches will take place. Since the Saint-Bernard mobilization, every two or three years, a bright event is needed for our movement to remain visible. In the past few years, Cachan and the occupation of the Bourse du travail in 2008 have played that role. It was also the aim of this march in $2010 \ldots$. It is only during these types of events that our movement becomes popular and the government steps back, allowing some regularizations. ${ }^{18}$ [authors' translation]

This cognitive process of empowerment is also noticeable in the choice of the name 'Ministry for the regularization of all undocumented migrants', the occupied building that served as the

\footnotetext{
${ }^{17}$ Ibid.
}

${ }^{18}$ CSP 75, "Après le "Paris-Nice" des sans-papiers, pourquoi pas le "Tour de France" ou le “Paris-Dakar” des sans-papiers?', August 2010. 
starting point for the march. This name is a symbolic reappropriation of the political space: it is a way of claiming that undocumented migrants are part of the French polity and that they have the power to transform it through their actions. It is also a direct response to the controversial creation of the Ministère de l'immigration, de l'intégration, de l'identité nationale et du développement solidaire (French Ministry of Immigration, Integration, National Identity and Solidarity Development) in $2007 .{ }^{19}$ In other words, it is a manner in which to gain power over public authorities and to trigger a process of emancipation through participation in the public space.

In Germany, many of the debates organized during the tour related to previous experiences involving collective actions that were considered successful and encouraging:

Some examples were provided, which offered encouragement. Examples of successful fights against deportation, such as the occupations and hunger strikes of Iranian refugee-activists. . . . We also heard about the history of Debru E., a well known refugee-activist in Neuburg, who was almost deported a few months ago. Thanks to the solidarity of the Flüchtlingsrat and the Caravan, he managed to

\footnotetext{
${ }^{19}$ This ministry was the first in French history to relate specifically to the immigration issue. Its creation was one of the first measures undertaken by Nicolas Sarkozy after his election in 2007, and its name became very controversial almost immediately: the juxtaposition of the terms ‘immigration', 'integration' and 'national identity' were harshly criticized.
} 
avoid deportation and had his request for asylum recognized. ${ }^{20}$ [authors' translation]

This cognitive process of empowerment is also directly related to what the organization of the tour means for undocumented migrants. As a result, this tour is described as the expression of a space of 'freedom'. It represents an emancipation from their 'inhuman condition' in their countries of origin and from the 'internal borders' in Germany:

When most of us (migrants as well as refugees) left our destroyed countries, we did not leave as free women and men. We were forced to leave due to the unbearable and inhuman conditions that were imposed on us there.... With this tour, we express our freedom and overcome the internal borders imposed on us by the German government through the Residence Obligation Law against refugees. ${ }^{21}$ [authors' translation]

In fact, protestors claim that the simple fact of acting collectively is to regain power over processes of exclusion: 'We are prepared to take this course of action to achieve our freedom. For the space of our freedom today is the space of our common struggle. ${ }^{22}$ [authors' translation] ${ }^{20}$ Caravan for the Rights of Refugees and Migrants, 'Report of the second day of the tour in Neuburg', May 2007.

${ }^{21}$ Caravan for the Rights of Refugees and Migrants, 'Solidarity Against Deportation. Call for the CARAVAN tour from May 19 to June 4, 2007', May 2007

${ }^{22}$ Ibid. 
As our analysis illustrates, this cognitive process of empowerment takes on different, concrete forms depending on the context in which undocumented migrants mobilize. Thus, the comparison demonstrates that the degree of generality of discourses varies. In France, the movement appears to be more entrenched in society, and it develops claims related to work and to living conditions. At the other extreme of the continuum, in Germany, we observe that detention and deportation procedures are a central point of reference in the movement's discourses, referring to specific living conditions of undocumented migrants. The Quebec/Canada case appears to fall somewhere in between: activists refer to successful mobilizations from the past when staging their citizenship claims.

Nevertheless, beyond these specific instances, as the three marches illustrate, the cognitive processes have a common meaning: collective actions constitute a moment of collective empowerment through which undocumented migrants can behave as 'regular' citizens. By constructing an autonomous space of life, undocumented migrants convey the message that they are able to 'become political' (Isin, 2002: 275) and to become emancipated from the state of exception. Aside from building an autonomous space of life, the meaning of the marches also involves the issue of undocumented migrants' visibility and the emotional dimension of collective actions.

Building a space of visibility and the emotional dimension of collective actions 
As a form of collective action, the marches have been considered as a way in which to provide wide public exposure to participants and their cause. As a result, these actions have expressed a 'refusal to be invisible'. In Canada, this notion is illustrated by the fact that activists organized daily radio reports during the event and that they used highly visible artistic forms of expression during the course of the march.

The NO ONE IS ILLEGAL march includes interactive art and theatre elements to convey our opposition to borders, and our solidarity as human beings. . . . Our diversity, healthy craziness and human bonding will complement the anger, sweat and tears of our struggle for dignity and justice, as we march to Ottawa. This will be a true cultural event in which all the marchers can participate. Art, theatre and culture are a human right for all to enjoy and take part in! $!^{23}$

This strategy is linked to an emotional process: public visibility is both an expression and a trigger of feelings of pride among participants. This was clearly expressed in a newspaper-style document produced by Solidarity Across Borders and distributed to participants during the event:

We need to organize to make our voices heard, to unite with one cry, the cry of the oppressed. Our fight is one, our enemy is the same. Our fight is for life with dignity. Lift your faces in pride, for they have stolen everything but our dignity. ${ }^{24}$

\footnotetext{
${ }^{23}$ Solidarity Across Borders, 'Why We Are Marching', June 2005.

${ }^{24}$ Solidarity Across Borders, 'We Didn’t Cross the Border. The Border Crossed Us!', 2004.
} 
Through their collective actions, undocumented migrants escape the position of invisibility that they normally occupy because of the risk of police surveillance. They are symbolically situated at the heart of the public space. This process signifies a politicization of their presence because it directly challenges the institutional representation of their presence as being 'abnormal'. In other words, their presence is symbolically staged in the public space so that it will become a political fact.

Like the March to Ottawa, the march from Paris to Nice and the Caravan tour in Germany were viewed as events that enabled the definition and demonstration of feelings of pride (through highly visible forms of collective actions). The visibility of this collective action, and the emotional process that is associated with it, is underlined in a report prepared by the organizers of the march from Paris to Nice three months after the event:

All walkers feel like they have participated in something exceptional, from the reception that we received everywhere, as well as on a personal level, for the human relationships we developed with this experience, between local supporters and walkers or among walkers themselves, was quite unexpected. . . This "African" march (walking, dancing, drumming) has shown the ever-renewed strength of this banality, that it is not enough to lose themselves in discussions and planning around a table. Rather, there is a need to act, to walk in order to generate 
ideas and foster a spirit of initiative; it is often during action that things are built, developed and done at their best. ${ }^{25}$ [authors' translation]

In Germany, the public visibility gained during the course of the march was also presented as a way to reinforce the determination and pride of protestors:

The German immigration and asylum policies, its exclusion and deportation apparatus, were very clearly made public and were exposed to the people on the way to Heiligendamm. We brought the isolation of refugees to an end through our mutual solidarity. The resistance of refugees who are fighting against the deportation system was reinforced. ${ }^{26}$ [authors' translation]

These feelings of pride and determination were coupled with emotions of anger that emerged or that were reinforced during the tour. Long-term collective actions such as the tour do indeed constitute events during which personal experiences are shared and the injustice faced by some individuals becomes collective. As a result, during the tour in Germany, protestors organized several memorials of undocumented migrants who had died during their arrest by the police or during their deportation. In addition, they organized several protest actions in front of retention

${ }^{25}$ CSP 75, "Après le "Paris-Nice" des sans-papiers, pourquoi pas le "Tour de France" ou le “Paris-Dakar" des sans-papiers?', August 2010.

${ }^{26}$ Caravan for the Rights of Refugees and Migrants, 'Düsseldorf - Für eine Welt ohne Ausbeutung, Unterdrückung und Kriege - Solidarität gegen Abschiebung', May 2007. 
centres. In the course of these particular actions, protestors described themselves as being 'in a fighting-spirit' ${ }^{27}$ and 'very moved by the situation of these people'. ${ }^{28}$

The collective actions of undocumented migrants allow them to gain visibility in the public sphere and to put forward their claims with greater resonance. Beyond this instrumental dimension, however, public visibility is also a way to trigger and express emotions of pride among participants. As our comparative analysis shows, depending on the contexts in which undocumented migrants mobilize, feelings of pride can take on different forms. In Quebec, for instance, pride is more often associated with a collective identity defined in terms of country of origin than it is in Germany or in France. This could be related to Quebec's immigration policies, which were developed based on multiculturalism and interculturalism, as mentioned in the introduction. Also, in France, this feeling of pride is more often associated with an identification with a specific social class than it is in Germany or Quebec. This distinctiveness may be related to trade-unions' involvement in the movement, which is much more significant in France than in the two other cases.

However, beyond these differences, the emotional process has a common meaning. These three marches illustrate the fact that this process is highly symbolic: it is a direct challenge to the situation of invisibility of undocumented migrants in the state of exception and to the feelings of

${ }^{27}$ Caravan for the Rights of Refugees and Migrants, 'Kämpferisch gegen Abschiebehaft in Büren', May 2007.

${ }^{28}$ Caravan for the Rights of Refugees and Migrants, 'Das Lager muss weg! Karawane-Station in Freienbessingen', June 2007. 
dehumanization associated with the 'bare life'. In the last section of the paper, we focus on the relational dimension and illustrate the specific meaning of solidarity-building through the mobilizations of undocumented migrants.

\section{Relational effects and the building of solidarities}

Protest events constitute an instance of solidarity-building between undocumented migrants and other activists outside their networks. It is also an instance during which solidarities among migrants are deepened. Since they are long-term actions, marches are probably the most illustrative examples of this dynamic of 'networking in action' (della Porta, 2008). These two dimensions were therefore underscored by the group Solidarity Across Borders during the march from Montreal to Ottawa:

By demanding Status for All we want to break the fear and isolation associated with the reality of being a non-status person. A Status for All demand rejects the divide-and-rule tactics used by the state to classify migrants as "deserving" versus "undeserving", or "good" versus "bad" immigrants. We aim to create genuine solidarity and support between all migrants, whether they are new immigrants, undocumented workers, refugees, or temporary workers. ${ }^{29}$

${ }^{29}$ Solidarity Across Borders, "Status For All!”, 2011 
For Solidarity Across Borders, one of the main objectives of this march was to redefine the relationships among undocumented migrants and between undocumented workers and other citizens. This goal was reached symbolically by the collective action itself: the fact that undocumented migrants were able to participate in the organization or implementation of this action meant that they had established connections of solidarity. In this regard (i.e., beyond the outcome of this action), the activists extolled the success of the march.

In France, with the march from Paris to Nice and the occupation of a public building in Paris, undocumented migrants aimed to construct a space where they could foster solidarities and build a collective identity. Thus, activists organized many different activities in the area they occupied: it was designed as a logistical place for activist meetings, where undocumented migrants could converge and join the movement, as well as a 'space of political, cultural and life meetings' ${ }^{30}$ In this perspective, the occupation has been permanently linked with the march (it coordinated its progress and broadcasted daily videos through its website):

We have organized all sorts of events in this place: concerts, drop-in days, film showings, festivals, etc. We have also developed various activities: language and computer courses, Velorution workshops, book workshops, video workshops. . . . This has served to demonstrate that, aside from our political fight, we were able to

\footnotetext{
${ }^{30}$ Ministère pour la Régularisation de Tous les Sans-Papiers, 'Appel du Ministère pour le 7 aout!', July 2010.
} 
escape the condition of isolation in which the government intends to keep us. ${ }^{31}$ [authors' translation]

As a result, the occupation was developed as a way to demonstrate publicly that undocumented migrants were able to 'escape their condition of isolation'. What is meant by the term 'isolation' here is both a condition of individual isolation-the notion that undocumented migrants cannot organize in solidarity-and a more general condition of isolation of undocumented migrants in society. This relational dimension concerns more than the consolidation of solidarity ties between undocumented migrant activists; these collective actions were also meant as a way to construct solidarities with potential supporters:

Thanks to your support and to the demonstrations and debates you organized, this march is already a success. The diversity of organizations, associations, unions and individual support strongly show that the treatment of undocumented migrants has a favourable echo in the population.... Struggles of undocumented migrants, precarious workers, the unemployed and retired people participate in the same battle conducted by workers to guarantee their living conditions, which include the protection of their wages, but also the right to accessible health services for all and the right to housing among other things. ${ }^{32}$ [authors' translation]

\footnotetext{
${ }^{31}$ Ibid.

${ }^{32}$ Ministère pour la Régularisation de Tous les Sans-Papiers, 'Remerciements à tous nos soutiens', June 2010.
} 
As shown in the above quotation, the march is itself a form of emancipation from the state of exception given that it produced solidarity ties between undocumented migrants and other social groups. Consequently, this process also involved a linking of the claims of undocumented migrants to those of other social groups.

In the 'Caravan-Tour 2007' in Germany, for instance, this process took the form of a day devoted entirely to the 'exchanges and socialization between activists of the Caravan-network and residents in the Neuburger refugee-camp ${ }^{33}$. This relational process is also more general in nature and is related to the construction of ties with other movements, in view of the protest against the G8 in Heiligendamm:

The point is to use the summit as a symbol of global ruling relationships, to criticize the existing circumstances and to carry discussions about alternatives into society. For us, the G8 summit is simply the occasion; far beyond this, our purpose is common resistance..$^{34}$ [authors' translation]

From these examples, we see that in addition to the cognitive and emotional processes, the collective actions of undocumented migrants also signify an emancipation from the state of

${ }^{33}$ Caravan for the Rights of Refugees and Migrants, 'Report of the second day of the tour in Neuburg', May 2007

${ }^{34}$ Alliance of anti-G8-caravans Oldenburg, 'Resistance without boundaries!!!', May 2007 
exception with respect to the relational dynamics. In the course of their protests, activists strive to act in solidarity and strengthen their connections.

Again, these relational processes assume different forms depending on the context in which undocumented migrants mobilize. For instance, in Germany, where much of the mobilization is related to the Residenzpflicht, the primary aim is to strengthen the connections between undocumented migrants. In France and in Quebec, given that mobilizations are more often related to diversified experiences (e.g., working or housing conditions), the primary aim is more often to build connections with actors from other fields. Also, since the French movement is comparatively more established, the aim is to consolidate the connections, while in Germany and Quebec (where these movements are more recent or less resonant), the aim is rather to build the connections.

However, beyond these differences, the examples of the three marches demonstrate that these relational processes have a common meaning. As they act collectively in the public space, undocumented migrants convey the message that they are able to emancipate themselves from social isolation and build solidarities.

As these three marches illustrate, mobilizations of undocumented migrants, as collective acts of emancipation, challenge the state of exception in which they are placed by public authorities. Acting collectively, they redefine power relations and construct leeway for themselves within society. These collective actions have cognitive, emotional and relational effects: they aim to empower undocumented migrants, create feelings of pride and foster relationships of solidarity. 
These three processes are not new, and other studies have shown their significance in several movements (della Porta, 2008). However, they have a specific meaning for undocumented migrants. As these marches have shown, undocumented migrants symbolically redefine their presence and situate themselves outside the state of exception. In the course of their marches, undocumented migrants consciously 'stage' their presence in the public space in order to contest the state of exception. These actions allow them to move from a position of individual isolation and invisibility to a situation where they can act collectively, occupy the public space and influence the features of this space. As a result, undocumented migrants invent strategies in order to concretely challenge their status in the course of the protest. Through their mobilizations, undocumented migrants cause new horizons of action to emerge and foster discourses that signify an emancipation from the state of exception.

\section{Conclusion}

Studies inspired by neo-institutionalist approaches have shown that the cultural dimension of collective actions is shaped, from the outset, by the political context in which it takes place. Our empirical analysis demonstrates that the symbolic dimension of the collective actions of undocumented migrants is similar in different contexts. We used a two-step approach to explain this empirical puzzle.

First, we based our analysis on a conceptualization of the symbolic component of collective actions by focusing on power relations. From this perspective, we have shown that the mobilizations of undocumented migrants possess strong symbolic similarities across contexts 
because they concern people who face a unique form of power relation: their condition is heavily determined by the disciplinary management and humanitarian assistance on the part of public authorities.

Next, we suggested that this 'exceptional' (i.e., in the sense of a state of exception) form of power relation provides a specific meaning to the mobilizations of undocumented migrants. Their collective actions are a way to create autonomous spaces of life, spaces of visibility where they claim their public existence and spaces of solidarity among people living in the same situation, as well as between them and other social groups. These performances are symbolic because they signify an emancipation from the state of exception.

This conclusion does not invalidate the argument that context has an influence on the symbolic aspects of collective actions. As we have seen, for each criterion considered (cognitive, emotional and relational), some variations do exist among our cases. Nevertheless, at a certain level of generalization, it is possible to ascertain meanings in the collective actions of undocumented migrants. The situation of formal radical exclusion in which they live appears to trigger a common pattern of resistance and reactions: collective actions are a way to seek (and create) emancipation.

The specific focus of our analysis raises several other questions. First, are our results valid for the mobilizations of undocumented migrants taking place elsewhere? Our argument would lead to an affirmative answer, at least in countries where the rule of law is strongly developed and applied. Obviously, other empirical evidence will be necessary to support this affirmation, but 
we believe that our cases are sufficiently different in terms of context (i.e., Germany, France and Canada are three countries with different philosophies of integration), which means that the argument should hold for other democratic societies as well.

Is our analysis valid for the mobilizations of other excluded or marginalized groups? Undocumented migrants are 'the excluded among the excluded' (Balibar, 2000) and consequently occupy a very specific social position relative to other social groups. However, we could argue that the extreme case of undocumented migrants makes the particularities of the mobilizations of the excluded more visible overall. In this regard, we propose as a working hypothesis that the more people face exclusionary power relations, the more their collective actions will possess the features of 'acts of emancipation'.

\section{References}

Agamben, G., 1997. "The Camp as Nomos of the Modern”. In H. de Vries and S. Webe, ed. Violence, Identity and Self-Determination. Stanford: Stanford University Press, pp.106-118.

Agamben, G., 1998. Homo Sacer: Sovereign Power and Bare Life. Stanford: Stanford University Press.

Agamben, G., 2000. Means Without End: Notes of Politics. Minneapolis: University of Minnesota Press.

Armstrong ,E., and Bernstein, M., 2008. "Culture, Power, and Institutions: A Multi-Institutional Politics Approach to Social Movements", Sociological Theory, 26 (1), pp. 74-99. 
Balibar, E., 2000. "What we owe to the Sans-Papiers". In L. Guenther and C. Heesters, ed. Social Insecurity: Alphabet City No. 7. Anansi: Toronto, pp.42-43.

Bernstein, M., 1997. "Celebration and Suppression: The Strategic Uses of Identity by the Lesbian and Gay Movement”. American Journal of Sociology, 103(1), pp.531-65.

Bigo, D., 2007. "Detention of Foreigners, States of Exception, and the Social Practices of Control of the Banopticon”. In P. K. Rajaram, and C. Grundy-Warr, ed. Borderscapes: Hidden Geographies and Politics at the Territory's Edge. Minneapolis: University of Minnesota Press, pp.3-33.

Bouchard, G. and Taylor, C., 2008. Commission de consultation sur les pratiques d'accommodement reliées aux différences culturelles, Rapport final. Québec: Gouvernement du Québec.

Borkert, M. and Bosswick, W., 2007. "Migration Policymaking in Germany: Between National Reluctance and Local Pragmatism”, IMISCOE Working Paper No. 20.

Brubaker, R., 1992. Citizenship and Nationhood in France and in Germany. Cambridge: Cambridge University Press.

Brubaker, R., 2001. "The Return of Assimilation? Changing Perspectives on Immigration and its Sequels in France, Germany, and the United States”. Ethnic and Racial Studies, 24(4), pp. 531548.

Buckel, S. and Wissel, J., 2010. "State Project Europe: The Transformation of the European Border Regime and the Production of Bare Life". International Political Sociology, 4(1), pp.3349.

Chabanet, D., 2002. "Les marches européennes contre le chômage, la précarité et les exclusions". 
In R. Balme, D. Chabanet and V. Wright, ed. L'action collective en Europe. Paris: Presses de Sciences Po.

Courau, H., 2008. "Undocumented Migration Counting the Uncountable. Data and Trends across Europe", Country report France for the research project Clandestino, www.clandestino.eliamep.gr (accessed September 10, 2010).

Cyrus, N., "Undocumented Migration Counting the Uncountable. Data and Trends across Europe", Country report Germany for the research project Clandestino, www.clandestino.eliamep.gr (accessed September 10, 2010).

della Porta, D., 2008. "Eventful protest, global conflicts". Paper presented at the plenary session of the Conference of the Nordic Sociological Association, Aahrus.

Diken, B., 2004. "From Refugee Camps to Gated Communities - Biopolitics and the End of the City". Citizenship Studies, 8(1), pp.83-106.

Dufour, P., Masson, D. and Caouette, D., 2010. Solidarities beyond Borders. Transnationalizing Women Movements. Vancouver : UBC Press.

Edkins, J. and Pin-Fat, V., 2005. "Through the Wire: Relations of Power and Relations of Violence”. Millennium - Journal of International Studies, 34(1), pp.1-27.

Evans, J., 1997. "Multi-Organizational Fields and Social Movement Organization Frame Content: The Religious Pro-Choice Movement”. Sociological Inquiry, 67 (4), pp.451-469.

Fassin, D., Morice, A., and Quiminal, 1997. Les Lois de l'Inhospitalité, Paris: La Découverte.

Fassin, D., 2005, “Compassion and Repression: The Moral Economy of Immigration Policies in France”, Cultural Anthropology, 20(3), pp.362-387. 
Favell, A., 1998. Philosophies of Integration: Immigration and the Idea of Citizenship in France and Great-Britain. London: McMillan.

Goodwin, J., Jasper, J., and Polletta, F., 2001. Passionate Politics. Emotions and Social Movements, Chicago: the University of Chicago Press.

Hamel, P., 1995.Collective action and the Paradigm of Individualism. In L., Maheu, ed., Social Movements and Social Classes. The Future of Collective Action. London: Sage, pp.236-257.

Heckmman, F., 2003. "From Ethnic Nation to Universalistic Immigrant Integration: Germany". In Heckmann, F. and Schnapper, D. (eds.), The Integration of Immigrants in European Societies. National Differences and Trends of Convergence, Stuttgart: Lucius, pp. 45-78.

Herbert, U., 2001. Geschichte der Ausländerpolitik in Deutschland. Saisonarbeiter, Zwangsarbeiter, Gastarbeiter, Flüchtlinge, Munich: Beck

Hindess, B., 2004. “Citizenship for All”. Citizenship Studies, 8(3), pp.305-315.

Benford, R., and Hunt, S., 1992, "Dramaturgy and Social Movements: The Social Construction and Communication of Power", Sociological Inquirv, 62(1), pp. 36-55

Isin, E., 2002. Being Political: Genealogies of Citizenship, Minneapolis: University of Minnesota Press

Isin, E., 2009, “Citizenship in flux: The figure of the activist citizen”, Subjectivity, 29, pp. 367388

Isin, E. and Nielsen, G., 2008. Acts of Citizenship. London: Zed Books.

Jasper, J., 1997. The Art of Moral Protest. Culture, Biography, and Creativity in Social Movements. Chicago: University of Chicago Press. 
Johnston, H., and Klandermans, B., ed., 1995. Social Movements and Culture. Minneapolis: University of Minnesota Press.

Khandor, E., McDonald, J., Nyers, P., and Wright, C., 2004. "The Regularization of Non-Status Immigrants in Canada 1960-2004. Past Policies, Current Perspectives, Active Campaigns", www.ceris.metropolis.net, accessed June 3, 2009

Kobelinsky, C. and Makaremi, C., 2008. "Le Confinement des étrangers : entre circulation et enfermement", Cultures et Conflits, 71, pp.7-29.

Koopmans, R., and Statham, P., 1999. "Political Claims Analysis: Integrating Protest Event and Public Discourse Approaches", Mobilization, 4(2), pp.203-222

Koopmans, R., Statham, P., Giugni, M., and Passy, F., 2005. Contested Citizenship: Immigration and Cultural Diversity in Europe. Minneapolis: University of Minnesota Press.

Kumar Rajaram, P., and Grundy-Warr, C., 2004. "The Irregular Migrant as Homo Sacer:

Migration and Detention in Australia, Malaysia and Thailand", International Migration, 42(1), pp.33-64

Kymlicka, W., 1995. Multicultural Citizenship. Oxford: Oxford University Press.

Labelle, M., Rocher, F., and Antonius, R., 2009. Immigration, diversité et sécurité. Les associations arabo- musulmanes face à l'État au Canada et au Québec. Québec: Presses de l'Université de Québec.

Lomnitz, C., 2007. Immigrant Mobilizations in the United States. In M. Feher, G. Krikorian, and Y. McKee, ed., Nongovernmental Politics. New York: Zone Books.

McAdam, D., 1982. Political Process and the Development of Black Insurgency, 19301970, Chicago: The University of Chicago Press. 
Marx Ferree, M ., Gamson, M. W. A., Gerhards, J. And Rucht, D., 2002. Shaping Abortion Discourse. Democracy and the Public Sphere in Germany and the United States. Cambridge: Cambridge University Press.

Nyers, P., 2003, “Abject Cosmopolitanism: The Politics of Protection in the Anti-Deportation Movement" Third World Quarterly, 24(6) pp.1069-1093

Nyers, P., 2008. "No One is Illegal between city and nation”. In E. Isin and G. Nielsen, Acts of Citizenship. London: Zed Books, pp. 160-181.

Polletta, F., 2002. Freedom is an endless meeting: Democracy in American social movements. Chicago: University of Chicago Press.

Polletta, F., 2004. “Culture Is Not Just In Your Head”. In J. Goodwin and J. Jasper, ed., Rethinking Social Movements. Structure, Meaning and Emotion. Lanham: Rowman and Littlefield, pp.97-110.

Polletta, F., 2008. "Culture and Movements". The ANNALS of the American Academy of Political and Social Science, 619(1), pp.78-96.

Schnapper, D., 2004, “The Concept of 'Dominant Ethnicity' in the Case of France”, In E. P. Kaufmann (ed.), Rethinking Ethnicity. Majority Groups and Dominant Minorities, London, Routledge, pp.102-115

Sewell, W., 1996, "Historical Events as Transformations of Structures: Inventing Revolution at the Bastille", Theory and Society, 25(6), pp.841-81.

Siméant, J., 1998. La cause des sans-papiers. Paris: Presses de Sciences Po.

Swidler, A., 1986, "Culture in Action: Symbols and Strategies”, American Sociological Review, 51(2), pp.273-86. 
Swidler, A., 2001, Talk of Love: How Culture Matters, Chicago: University of Chicago Press.

Walters, W., 2008. "Acts of demonstration : mapping the territory of (non-)citizenship". In E.

Isin and G. Nielsen. Acts of Citizenship. London: Zed Books, pp.182-205.

Williams, R., 2004. "The Cultural Context of Collective Action: Constraints, Opportunities, and the Symbolic Life of Social Movements". In D. Snow, S. Soule and H. Kriesi, ed., The Blackwell Companion of Social Movements. Oxford: Blackwell Publishing, pp.91-115. 